\title{
Neurological Spectrum of COVID-19: A Practical Review
}

\section{COVID-19’un Nörolojik Görünümü: Pratiğe Yönelik Gözden Geçirme}

\author{
1 Hacettepe University Faculty of Medicine, Department of Neurology, Neurology Intensive Care Unit, Ankara, Turkey \\ 2Selcuk University Faculty of Medicine, Department of Neurology, Neurointensive Care Unit, Konya, Turkey
}

\begin{abstract}

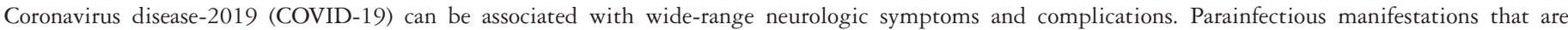

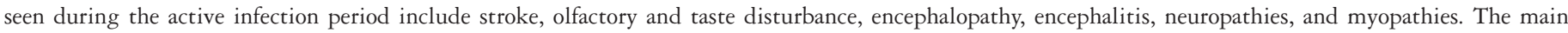

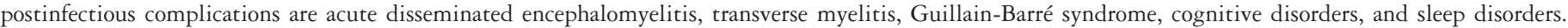

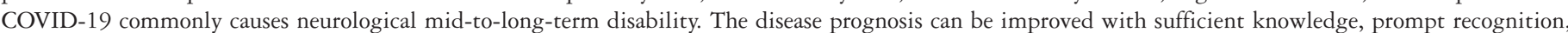
and effective management of neurological complications.
\end{abstract}

Keywords: SARS-CoV-2, COVID-19, brain, cerebral, neurological, neuromuscular

Öz

Koronavirüs hastalığı-2019 (COVID-19) çok farklı nörolojk semptom ve komplikasyonlarla birlikte olabilir. Aktif enfeksiyon döneminde görülen paraenfeksiyöz manifestasyonlar inme, koku ve tat bozukluğu, ensefalopati ve ensefalit ile nöropati ve miyopatileri içerir. Postenfeksiyöz komplikasyonların başlıcaları akut dissemine ensefalomiyelit, transvers miyelit ve Guillain-Barré sendromu, kognitif bozukluklar ve uyku bozukluklarıdır. COVID 19’un uzun dönemde nörolojik disabiliteye yol açması nadir değildir. Nörolojik komplikasyonların yeterince bilinmesi, zamanında tanınması ve etkili yönetimi ile hastalık prognozu iyileştirilebilir. Anahtar Kelimeler: SARS-CoV-2, COVID-19, beyin, beyin, nörolojik, nöromüsküler

\section{Introduction}

Herein, reviewed the neurological complications associated with coronavirus disease-2019 (COVID-19) in the days in which the number of patients in our country exceeds 8 million and the number of deaths exceeds 70,000, in the fourth wave of the pandemic, which deeply affects every aspect of our lives (1). The Turkish Neurological Society had published a series of evaluations on the subject in the first wave of the pandemic $(2,3,4)$. However, the knowledge accumulation in the interim period necessitated an update.

COVID-19 due to severe acute respiratory syndrome coronavirus-2 (SARS-CoV-2) affects all neural structures. Additionally, neurological disorders appear on an average of 2 days after the onset of viral symptoms in approximately $15 \%$ of patients (5).
Neuropathological studies revealed that COVID-19related neurological events occur not as a result of a direct viral cytopathic effect on neuroglial tissue, but rather as a result of other mechanisms, such as immune-mediated inflammation, cytokine storm, systemic inflammation, and hemodynamic disorders. Therefore, neurological syndromes of COVID-19 are examined in two groups as "parainfectious," which is seen during the disease period, and "postinfectious," after disease control (Table 1) (6).

\section{Parainfectious Neurological Syndromes}

Patients with COVID-19 encountered the most common neurological disorders during the symptomatic viral period in the early disease period, which is all examined within the scope of "parainfectious syndromes," such as anosmia, ageusia, encephalopathy (metabolic and/or hypoxic), viral

Address for Correspondence/Yazışma Adresi: Mehmet Akif Topçuoğlu Prof. MD, Hacettepe University Faculty of Medicine, Department of Neurology, Neurology Intensive Care Unit, Ankara, Turkey Phone: +90 31230518 06 E-mail: mat@ hacettepe.edu.tr ORCID: orcid.org/0000-0002-7267-1431

Received/Geliş Tarihi: 06.12.2021 Accepted/Kabul Tarihi: 06.12.2021

${ }^{\circledR}$ Copyright 2021 by Turkish Neurological Society

Turkish Journal of Neurology published by Galenos Publishing House. 


\begin{tabular}{|ll|}
\hline Table 1. Neurological complications of COVID-19 \\
Parainfectious & $\begin{array}{l}\text { Postinfectious } \\
\text { Scute disseminated } \\
\text { encephalomyelitis }\end{array}$ \\
$\begin{array}{l}\text { Encephalopathy (metabolic/ } \\
\text { hypoxic) }\end{array}$ & Brain stem encephalitis \\
Viral meningoencephalitis & Myelytic syndromes \\
Stroke & Guillain-Barré syndrome \\
$\begin{array}{l}\text { Acute necrotizing } \\
\text { hemorrhagic encephalopathy }\end{array}$ & $\begin{array}{l}\text { Long-term COVID-19 } \\
\text { syndrome }\end{array}$ \\
Myositis & $\begin{array}{l}\text { Multiple systemic } \\
\text { inflammatory syndromes }\end{array}$ \\
$\begin{array}{l}\text { Central neurogenic } \\
\text { hypoventilation }\end{array}$ & Cognitive disorders \\
covid-19: Coronavirus disease-2019 & \\
\hline
\end{tabular}

meningoencephalitis, central hypoventilation, stroke, acute necrotizing hemorrhagic encephalitis, and myositis.

Anosmia and Ageusia: The loss of smell and taste is one of the most popular disease symptoms that develop in approximately $50 \%$ of patients, mostly in the early stages. However, according to detailed tests, the rate of olfactory disorder reaches $90 \%$. The loss of smell and taste is reversible in most patients, but prolonged hyposmia, parosmia, or cacosmia may occur. The main mechanism of olfactory loss is the viral infection of the sustentacular cells that are located in the olfactory mucosa and abundantly express the SARS-CoV-2 receptor angiotensin-converting enzyme 2 . These cells are close to the olfactory nerve endings. The pathological evidence of olfactory nerve viral involvement is unavailable. All magnetic resonance imaging studies that claim the olfactory system involvement is controversial. Additionally, no convincing evidence for direct viral infection of the olfactory nerve has been presented (7).

Myalgia and Fatigue: Similar to other viral infections, muscle pain, weakness, and fatigue are quite common (50\%) and may persist for a long time in many patients. Headache $(8 \%)$ and diarrhea $(5 \%)$ are less common but may be the predominant finding in some patients (8).

Stroke: The stroke encountered in patients with COVID-19 shows slight differences compared to other patients in the general characteristics and management; however, this situation is not evident (9). The mean prevalence of stroke in patients who are positive COVID-19 is approximately $1.5 \%$ (10). Cerebral venous thrombosis and simultaneous multiple arterial occlusion and microhemorrhages were more commonly reported in some series (2). Stroke often develops due to classical causes. Some patients present COVID-19-associated coagulopathy, antiphospholipid antibody formation, COVID-19-associated cardiomyopathy, or embolism due to myocarditis or cerebrovascular endotheliitis but are difficult to demonstrate. However, effective acute stroke treatment is essential, especially in patients with severe COVID-19, and should not be neglected. Thrombectomy and/or thrombolytic therapy quality metrics should not be compromised in COVID-19 (11,12,13).

Encephalopathy: Encephalopathy is more frequently seen in at least $1 / 3$ of patients who are hospitalized due to COVID-19, as well as the elderly. The rate of encephalopathy increases even more in patients with COVID-19 in the intensive care units (2/3) (10). Encephalopathy can generally be explained by hypoxic and/ or metabolic causes and fits into the syndromes that are defined for patients in the intensive care unit. Regardless of the cause, the prognosis of patients with encephalopathy and COVID-19 is worse. Some patients who were reported with encephalitis may be an exaggerated interpretation of the complex manifestation of hypoxic, septic, ischemic (hypotensive), metabolic, and toxic (oversedative/hypnotic, anticholinergic, and steroid) encephalopathies.

Meningoencephalitis: COVID-19 probably does not directly cause encephalitis. Autopsy studies show a generally very low concentration of SARS-CoV-2 mRNA and proteins and copy number in the brain, without topographical correlation with astrogliosis, ischemic, and inflammatory changes (14). A specific pattern of cerebral involvement was not detected in a few patients with positive viral polymerase chain reaction (PCR) in the cerebrospinal fluid (CSF). The observed findings are likely to result from blood contamination or endotheliitis and microhemorrhages that are directly caused by viremia (15).

Acute Necrotizing Hemorrhagic Encephalopathy: This is a critical disorder that occurs due to cytokine storm that develops in the process, not as a result of direct viral neuroinvasion, known from influenza. It progresses with the bilateral thalami, basal ganglia, temporal lobes, and brain stem involvement. Its features include no contrast enhancement in hemorrhagic and edematous lesions and that a response to plasmapheresis and intravenous immunoglobulin (IVIG), not steroids $(16,17)$.

\section{Postinfectious Neurological Syndromes}

Post-COVID-19 neurological syndromes include acute disseminated encephalomyelitis (ADEM), brainstem encephalitis, myelitis spectrum, Guillain-Barré syndrome (GBS) and variants, "multiple systemic inflammatory syndromes," and "prolonged COVID-19 syndrome”.

Acute Disseminated Encephalomyelitis: Post-COVID-19 ADEM generally fits the situation that is defined for other viral infections and are eminently common in adults, with common hemorrhagic lesions, and its risk is correlated with the severity of pulmonary COVID-19, with a high mortality rate (18). It is characterized by multiple large, coalition, and simultaneous demyelinating lesions. The virus cannot be isolated from the CSF. High-dose steroid is the main element in treatment (19).

Myelitis: Longitudinal acute transverse myelitis is most commonly reported, together with acute transverse myelitis, acute necrotizing myelitis, myelitis within the ADEM spectrum, neuromyelitis optica spectrum disorder, hypoxic myelopathy, MOG antibody-associated myelitis, spinal infarction, or spinal epidural abscess. Standard treatment methods are applied; however, the need for long-term rehabilitation is frequent (20).

Guillain-Barré Syndrome: Its frequency in patients with COVID-19 has been calculated to be 15 per hundred thousand. The distribution of clinical variants, such as Miller Fisher syndrome or cranial neuropathy, is similar to that of classical GBS. Albuminocytological dissociation in CSF can be demonstrated in $70 \%$ of patients. SARS-CoV-2 PCR in CSF is always negative. Good results are obtained using IVIG in at least $70 \%$ of patients (21). 


\section{Prolonged COVID-19 Syndrome}

Some patients with COVID-19 have "prolonged COVID-19" independent of the severity of the acute phase and become almost permanent at a rate of up to one-third. It is mainly a postviral syndrome; however, it occurs even in patients with relatively mild symptoms in the acute phase and overlaps with "post-intensive care syndrome," a collection of physical, mental, and emotional symptoms that persist after leaving the intensive care unit. Persistent viral replication, which continues at low severity is emphasized in its pathophysiology (6).

Prolonged COVID-19 includes three clinical syndromes and is common in combinations in the same patient.

Dysotonomic Syndrome (Type 1 Prolonged COVID-19 Syndrome): Postural orthostatic tachycardia syndrome is manifested by postural hypotension or hypertension, gastroparesis, and constipation, with possible fever and dry mouth.

Exercise Intolerance (Type 2 Prolonged COVID-19 Syndrome): Autonomic, cardiac, or musculoskeletal disorders, as well as pulmonary dysfunction, may contribute.

Cognitive Dysfunction (Type 3 Prolonged COVID-19 Syndrome): This disorder is also called "brain fog," where the habitual capacity of individual thought processes regresses.

Combinations of time distortion, short-term memory loss, symptoms of depression, and sleep disturbance occur.

\section{COVID-19 Vaccines and Neurology}

The first two mRNA-based vaccines have a high safety profile. However, a few patients with Bell's palsy or anaphylaxis-like reactions have been reported. However, the reported patients with stroke, transverse myelitis, ADEM, GBS, vertigo, and facial paresthesia due to mRNA vaccines or coincidental remains unclear (22).

Patients with cerebral venous thrombosis have been reported with adenovirus-vector vaccines. It is seen more frequently in women under 45 years of age, on average 10 days after vaccination; however, it is rare and its frequency is $<1$ in 500 thousand. Autoantibodies are produced against platelet factor 4, thus patients with vaccine-induced (23) thrombotic thrombocytopenia (English acronym "VITT") should not be treated with heparin. IVIG and non-heparin anticoagulation are suitable (24).

\section{Conclusion}

Therefore, COVID-19-related neurological manifestations appear to be relatively rare and manageable, given the enormous virus-infected population. However, prospective studies based on multidisciplinary collaboration should be emphasized to reveal the possible causal relationship between the virus and developing neurological disorders.

\section{Ethics}

Peer-review: Internally peer-reviewed.

\section{Authorship Contributions}

Concept: M.A.T., Ş.Ö., Design: M.A.T., Ş.Ö., Data Collection or Processing: M.A.T., Ş.Ö., Analysis or Interpretation: M.A.T., Ş.Ö., Literature Search: M.A.T., Writing: M.A.T.

Conflict of Interest: No conflict of interest was declared by the authors.

Financial Disclosure: The authors declared that this study received no financial support.

\section{References}

1. WorldMeter. Daily New Cases in Turkey. Last Accessed Date: 31.10.2021. Available from: https://wwwworldometersinfo/coronavirus/country/turkey/

2. Acar T, Demirel EA, Afşar N, et al. The COVID-19 from neurological overview. Turk J Neurol 2020;26:56-106.

3. Ozturk S. The COVID-19 from neurological overview. Turk J Neurol 2020;26:56-57.

4. Mengi T, Şirin H, Yaka E, et al. Brain death diagnosis and management in the pandemic: expert opinion of the Turkish Neurological Society Neurological Intensive Care Scientific Working Group. Turk J Neurol 2021;27.

5. Frontera JA, Sabadia S, Lalchan R, et al. A prospective study of neurologic disorders in hospitalized patients with COVID-19 in New York City. Neurology 2021;96:e575-e586.

6. Nath A. neurologic manifestations of severe acute respiratory syndrome coronavirus 2 infection. Continuum (Minneap Minn) 2021;27:1051-1065.

7. Balcom EF, Nath A, Power C. Acute and chronic neurological disorders in COVID-19: potential mechanisms of disease. Brain 2021; awab302.

8. Karadas O, Ozturk B, Sonkaya AR. A prospective clinical study of detailed neurological manifestations in patients with COVID-19. Neurol Sci 2020;41:1991-1995.

9. Topcuoglu MA, Pektezel MY, Oge DD, et al. Stroke mechanism in COVID-19 infection: a prospective case-control study. J Stroke Cerebrovasc Dis 2021;30:105919.

10. Misra S, Kolappa K, Prasad M, et al. Frequency of neurologic manifestations in COVID-19: a systematic review and meta-analysis. Neurology 2021;97:e2269-e2281.

11. Topçuoğlu MA, Arsava EM, Özdemir AÖ. Acute ischemic stroke treatment in covid-19 pandemia: expert opinion. Turk J Cerebrovasc Dis 2020:91-94.

12. Altunışık E, Arık A. Decreased stroke applications during pandemic: collateral effects of COVID-19. Turk J Neurol 2021;27:171-175.

13. Ozturk S. COVID-19 and stroke: a neurological perspective. In: Dehkharghani S (ed). Brisbane: Stroke, 2021.

14. Matschke J, Lutgehetmann M, Hagel C, et al. Neuropathology of patients with COVID - 19 in Germany: a post-mortem case series. Lancet Neurol 2020;19:919-929.

15. Kirschenbaum D, Imbach LL, Rushing EJ, et al. Intracerebral endotheliitis and microbleeds are neuropathological features of COVID-19. Neuropathol Appl Neurobiol 2021;47:454-459.

16. Poyiadji N, Shahin G, Noujaim D, et al. COVID-19-associated acute hemorrhagic necrotizing encephalopathy: imaging features. radiology 2020;296:E119-E120.

17. Varadan B, Shankar A, Rajakumar A, et al. Acute hemorrhagic leukoencephalitis in a COVID-19 patient-a case report with literature review. Neuroradiology 2021;63:653-661.

18. Manzano GS, McEntire CRS, Martinez-Lage M, Mateen FJ, Hutto SK. Acute disseminated encephalomyelitis and acute hemorrhagic leukoencephalitis following COVID-19: systematic review and meta-synthesis. Neurol Neuroimmunol Neuroinflamm 2021;8:e1080.

19. Wang Y, Wang Y, Huo L, et al. SARS-CoV-2-associated acute disseminated encephalomyelitis: a systematic review of the literature. J Neurol 2021;1-22.

20. Garg RK, Paliwal VK, Gupta A. Spinal cord involvement in COVID-19: a review. J Spinal Cord Med 2021:1-15.

21. Palaiodimou L, Stefanou MI, Katsanos AH, F, et al. Prevalence, clinical characteristics and outcomes of Guillain-Barre syndrome spectrum associated with COVID-19: a systematic review and meta-analysis. Eur J Neurol 2021;28:3517-3529.

22. Barda N, Dagan N, Ben-Shlomo Y, et al. Safety of the BNT162b2 mRNA Covid-19 Vaccine in a Nationwide Setting. N Engl J Med 2021;385:10781090 .

23. Palaiodimou L, Stefanou MI, Katsanos AH, et al. Cerebral venous sinus thrombosis and thrombotic events after vector-based COVID-19 vaccines: a systematic review and meta-analysis. Neurology 2021;97:e2136-e2147.

24. Warkentin T, Cuker A. COVID-19: Vaccine-induced immune thrombotic thrombocytopenia (VITT). Up-to-Date 2021. Last Accessed Date: 01.11.2021. Available from: https://www.uptodate.com/contents/covid-19vaccine-induced-immune-thrombotic-thrombocytopenia-vitt 